\title{
MORPHO-ANATOMY OF LEAVES AND YIELD OF PINEAPPLE PLANT IN INTERCROPPING WITH CASSAVA
}

\author{
MORFOANATOMIA FOLIAR E PRODUTIVIDADE DE ABACAXIZEIRO \\ CONSORCIADO COM MANDIOCA
}

\section{Roberto Aparecido CUSTÓDIO'; Sebastião Elviro de ARAÚJO NETO²; Paulo César Poeta FERMINO JUNIOR ${ }^{3}$; Romeu de Carvalho ANDRADE NETO ${ }^{4}$; Irene Ferro SILVA ${ }^{5}$}

1. Engenheiro Agrônomo, Mestre, Técnico da Prefeitura de Ouro Preto, RO, Brasil. robcustodio@ @hotmail.com; 2. Professor, Doutor, Programa de Pós Graduação em Produção Vegetal, Universidade Federal do Acre, UFAC, Rio Branco, AC, Brasil. selviro2000@yahoo.com.br; 3. Professor, Doutor, Universidade Federal de Santa Catarina, Florianópolis, SC, Brasil; 4. Professor, Doutor, Pesquisador da Embrapa, Acre, Rio Branco, AC, Brasil; 5. Engenheira Agrônoma, Mestre, Egressa do Programa de Pós Graduação em Produção Vegetal, Universidade Federal do Acre - UFAC, Rio Branco, AC, Brasil.

\begin{abstract}
The aims of this study were to evaluate the effects of shade in pineapple plant with cassava, on the yields of pineapple fruit sand cassava roots, on the morph-anatomical variation, damage by solar radiation and chlorophyll content of pineapple leaves. Pineapple plants were cultivated in plots comprising three parallel row sunder different shade conditions provided by cassava plants grown at various spacings within single rows located on either side of the plots. The experiment was of a randomized block design with five treatments (cassava spacings of $0.50,0.75,1.00$ and $1.25 \mathrm{~m}$ and a pineapple monoculture) and four replications. Yields of fruits and roots, together with the morphological, chemical and histological characteristics of the "D" leaves of pineapple, were determined14 months after planting the pineapples plant. Data were submitted to analysis of variance with the Scott-Knott test or Friedman test $(P<0.05)$ and to regression analysis. Pineapple plants grown under the majority of shade conditions presented higher fruit weight and overall yield per hectare in comparison with plants grown in direct sunlight. The maximum productivities of pineapple fruit were achieved when cassava plants were spaced $0.75 \mathrm{~m}$ apart and, under these shade conditions, fruits were fully protected against burning by the sun. The " $D$ " leaves of shaded plants were longer and thicker, with higher content of chlorophyll $a$ and total chlorophyll, reduced stomatal density and dimensions of stomatal pores, narrower guard cells, thinner aquiferous hypodermis, and reduced abaxial and adaxial epidermis. The yield of cassava roots per plant increased linearly with increasing distance between the plants, but the yield per hectare decreased with decreasing plant density.
\end{abstract}

KEYWORDS: Ananas comosus. Manihot esculenta. Phenotypic plasticity. Intercropping.

\section{INTRODUCTION}

Pineapple plant (Ananas comosus L. Merrill) is an herbaceous perennial that is well adapted to the climate and soil of tropical regions and is grown throughout the northern Brazilian state of Acre. Ecological cultivation of pineapple plant in this region is based on minimal addition of external inputs, and systems involving the use of green manure and intercropping with other species have been adopted widely as alternative forms of family farming (ANDRADE NETO et al., 2011). The pineapple plant in organic polyculture with passion fruit, maize and cassava represents a viable proposition as demonstrated by an average land-use efficiency of 2.65 (ARAÚJO NETO et al., 2014)

One of the major problems in the culture of pineapple plant in tropical regions relates to the high levels of solar radiation that burn or scold the outer layers of the fruit particularly during the maturation stage. According to the National Plant Classification System supported by the Brazilian Ministry of
Agriculture, the damage caused by fruit burning is considered a serious issue, which can result in a productivity loss of up to $70 \%$ depending on the harvesting season (CUNHA; HAROLDO, 2008).

Although cultivation of crops under shade conditions may provide a solution to this problem, alterations in luminosity can induce different anatomical, physiological and biochemical responses in dissimilar plant species and, consequently, variations in growth and photosynthetic efficiency (KIM et al., 2005). In some cases, plants exposed to intense solar radiation exhibit greater plasticity with an enhancement in photosynthetic capacity (DUZ et al., 2004). For example, the thickness of leaf tissues, mainly the epidermis and chlorophyll parenchyma, may increase in order to improve the dissipation of excess radiation (MARKESTEIJN et al., 2007; SARIJEVA et al., 2007), or the stomata, which exert significant influence on photosynthesis and leaf temperature, may vary in size and density allowing better regulation of gas exchange and transpiration 
(HETHERINGTON; WOODWARD, 2003; AL AFAS et al., 2006). In addition, the distribution and concentration of chlorophyll molecules are altered by solar irradiance (CARVALHO et al., 2010). In this manner, plasticity plays a significant role in the mechanism of plant adaptation to different light conditions.

Shading a crop with multiple species in a polyculture system is considered by many researchers to be an advantageous method for augmenting productivity and increasing the revenue of an agricultural unit (BEZERRA NETO et al., 2012) while, at the same time, reducing negative environmental impacts (CECÍLIO FILHO et al., 2011; PYPERS et al., 2011). The aims of this study were to evaluate the effects of shade in pineapple plant with cassava, on the yields of pineapple fruit sand cassava roots, on the morph-anatomical variation, damage by solar radiation and chlorophyll content of pineapple leaves.

\section{MATERIAL AND METHODS}

The intercropping of pineapple plant (Smooth Cayenne group; cultivar Rio Branco 1) and cassava (cultivar BRS Caipora) was performed at the Sítio Ecológico Seridó, Rio Branco, Acre, Brazil (9'53'16' S, 67\% $49^{\circ} 11^{\prime}$ ' W; altitude $170 \mathrm{~m}$ ) during the period March 2011 to November 2012. The region presents a tropical monsoon climate of type Am according to the Köppen classification. The soil is categorized as yellow clay with plinthite (argissolo amarelo alítico plíntico) according to the Brazilian Soil Classification System, with moderate drainage and no apparent signs of erosion. Chemical analysis of horizon A $(0-20 \mathrm{~cm})$ revealed the following characteristics: $\mathrm{pH} 5.1$; base saturation $29 \%$; organic matter $17 \mathrm{~g} \mathrm{dm}^{-3} ; \mathrm{P} 2 \mathrm{mg} \mathrm{dm}^{-3} ; \mathrm{K} 1.8$ $\mathrm{mmol}_{\mathrm{c}} \mathrm{dm}^{-3} ; \mathrm{Ca} 19 \mathrm{mmol}_{\mathrm{c}} \mathrm{dm}^{-3} ; \mathrm{Mg} 9 \mathrm{mmol}_{\mathrm{c}} \mathrm{dm}^{-3}$; Al $8 \mathrm{mmol}_{\mathrm{c}} \mathrm{dm}^{-3} ; \mathrm{H} 64 \mathrm{mmol}_{\mathrm{c}} \mathrm{dm}^{-3} ; \mathrm{Fe} 530 \mathrm{mg} \mathrm{dm}^{-}$ ${ }^{3}$; $\mathrm{Cu} 1.6 \mathrm{mg} \mathrm{dm}^{-3}$; Mn $99 \mathrm{mg} \mathrm{dm}^{-3} ; \mathrm{Zn} 2.6 \mathrm{mg} \mathrm{dm}^{-3}$ and $\mathrm{B} 0.17 \mathrm{mg} \mathrm{dm}^{-3}$.

The meteorological data recorded during the experiment are in Table 1.

Table 1. Meteorological data of the city of River Bank in the years 2011 and 2012. (Collected by the weather station of the Federal University of Acre)

\begin{tabular}{|c|c|c|c|c|c|c|c|c|}
\hline Mês/Ano & $\begin{array}{l}\text { Precipitação } \\
(\mathrm{mm})\end{array}$ & máxima & nperatura & média & $\begin{array}{c}\text { Umidade } \\
\text { Relativa } \\
(\%)\end{array}$ & $\begin{array}{c}\text { Evaporação } \\
\text { total (mm) }\end{array}$ & $\begin{array}{c}\text { Insolação } \\
\text { (hora/décimos) }\end{array}$ & $\begin{array}{c}\text { Nebulosidade } \\
(\%)\end{array}$ \\
\hline $01 / 2011$ & 116.9 & 30.3 & 22.7 & 25.6 & 87 & 49.7 & 118.3 & 8.3 \\
\hline $02 / 2011$ & 176.4 & 29.9 & 22.3 & 25.4 & 88 & 38.6 & 76.1 & 8.3 \\
\hline 03/2011 & 263.3 & 30.5 & 22.5 & 25.4 & 88 & 44.7 & 117.9 & 7.9 \\
\hline 04/2011 & 213.5 & 31.1 & 22.0 & 25.5 & 88 & 42.0 & 148.5 & 6.9 \\
\hline 05/2011 & 50.0 & 31.0 & 20.4 & 24.8 & 84 & 57.5 & 208.9 & 5.8 \\
\hline 06/2011 & 21.8 & 31.2 & 20.0 & 24.6 & 82 & 62.1 & 210.4 & 4.6 \\
\hline 07/2011 & 1.8 & 32.6 & 18.5 & 24.4 & 76 & 90.9 & 251.9 & 4.1 \\
\hline 08/2011 & 30.9 & 33.5 & 18.4 & 24.8 & 68 & 115.4 & 215.7 & 5.2 \\
\hline 09/2011 & 116.8 & 33.6 & 21.1 & 26.1 & 78 & 84.5 & 202.5 & 5.4 \\
\hline $10 / 2011$ & 99.9 & 32.2 & 22.1 & 26.0 & 84 & 68.2 & 160.7 & 7.5 \\
\hline $11 / 2011$ & 290.0 & 32.3 & 22.5 & 26.5 & 81 & 61.4 & 175.3 & 6.5 \\
\hline $12 / 2011$ & 127.2 & 31.2 & 22.8 & 25.9 & 87 & 49.1 & 134.7 & 7.5 \\
\hline $01 / 2012$ & 401.6 & 29.5 & 22.4 & 25.2 & 90 & 41.3 & 88.6 & 8.4 \\
\hline $02 / 2012$ & 452.4 & 29.8 & 21.9 & 25.1 & 89 & 39.0 & 83.5 & 8.1 \\
\hline 03/2012 & 316.8 & 31.0 & 22.0 & 25.5 & 87 & 47.6 & 153.2 & 7.7 \\
\hline $04 / 2012$ & 162.6 & 31.3 & 22.4 & 25.8 & 87 & 47.8 & 160.1 & 7.2 \\
\hline 05/2012 & 127.2 & 31.2 & 20.6 & 24.9 & 86 & 54.0 & 208.8 & 5.5 \\
\hline 06/2012 & 182.0 & 30.4 & 19.9 & 24.0 & 86 & 52.3 & 206.6 & 5.3 \\
\hline 07/2012 & 63.1 & 31.4 & 17.7 & 24.0 & 80 & 79.7 & 280.5 & 3.7 \\
\hline 08/2012 & 96.7 & 33.4 & 18.5 & 24.3 & 76 & 134.4 & 266.6 & 3.7 \\
\hline Average & 165.5 & 31.4 & 21.0 & 25.2 & 83.6 & 63.0 & 173.4 & 6.4 \\
\hline
\end{tabular}


The experiment was of a randomized block design and comprised five treatments with four repetitions each encompassing three rows of pineapple plant and two rows of cassava. In March 2011, following plowing and tilling of the experimental field, the pineapple propagules (500$600 \mathrm{~g}$ each) were planted at $0.80 \mathrm{~m}$ spacings in three rows $(0.25 \mathrm{~m}$ apart) according to the triangular arrangement. The external rows contained 24 pineapple plants each while the central row, considered the applicable plot, contained 18 plants to give a total of 15,000 plants $\mathrm{ha}^{-1}$. The treatments consisted of different degrees of shade provided by cassava plants, the stems of which were planted in the first week of September 2011 in single rows located on either side of, and $0.20 \mathrm{~m}$ from, the external rows of pineapple plant. Different densities of cassava were obtained by varying the spacings between the plants: spacing $0.50 \mathrm{~m}, 14,280$ plants ha $^{-1}$; spacing $0.75 \mathrm{~m}, 9,520$ plants $\mathrm{ha}^{-1}$; spacing 1.0 $\mathrm{m}, 7,140$ plants $\mathrm{ha}^{-1}$; and spacing $1.25 \mathrm{~m}, 5,712$ plants $\mathrm{ha}^{-1}$. In the control treatment, cassava plants were omitted so that the pineapple plant monoculture received direct sunlight. The cassava monoculture consisted of two rows $(1.0 \mathrm{~m}$ apart $)$ of plants with $1.0 \mathrm{~m}$ spacing $\left(10,000\right.$ plants $\left.\mathrm{ha}^{-1}\right)$ and received similar agricultural management as the intercropping system. In all treatments, $2 \mathrm{~m}$ roads were located between the plots.

Manual and mechanical weeding was performed (two and four times, respectively) as spontaneous weeds developed. No fertilizer was applied since the system intended to minimize the use of agricultural inputs. Infestation by fruit borers was controlled through application of a Bacillus thuringiensis-based insecticide $\left(\mathrm{DiPel}^{\circledR}\right)$ at the rate of $500 \mathrm{~g} \mathrm{ha}^{-1}$ every 15 days from flowering to fruit maturation. Flowering of the pineapple plants was induced 14 months after planting by applying $5 \mathrm{~mL}$ of $2 \%$ urea and $0.15 \%$ Ethrel $720^{\circledR}$ to the center of the crown leaves by pressure spray.

Morpho-anatomical analysis of " $D$ " leaves from 14 month-old pineapple plants were performed in the Tissue Culture Laboratory of Universidade Federal do Acre. Leaf length $(\mathrm{cm})$ was determined by measuring the longitudinal axis from the base to the apex, whereas leaf area $\left(\mathrm{cm}^{2}\right)$ was determined by tracing the contour of the leaf blade onto ordinary bond paper of constant density and cutting out the shapes so obtained. The area of the shape was calculated from the weight of the shape and the known density $\left(75 \mathrm{~g} \mathrm{~m}^{-2}\right)$ of the paper (VOLTOLINI; SANTOS, 2011).

The extraction and quantitative analyses of chlorophylls were performed according to the method described by Arnon (1949). Fresh "D" leaves from 14 month-old plants $(n=3)$ were collected in the morning, packed in black plastic bags, labeled, stored in polystyrene boxes lined with aluminum foil and transported to the laboratory. Fresh tissue $(0.5 \mathrm{~g})$ was removed from the median region of the middle-third of the leaf and macerated in $80 \%$ acetone using a pestle and mortar. The extract was centrifuged at $2200 \mathrm{rpm}$ for $2 \mathrm{~min}$ and the absorbance values at 654 and $663 \mathrm{~nm}$ of an aliquot of the supernatant were recorded using a spectrophotometer. The concentrations of chlorophylls $a$ and $b$ (Chl $a$ and $\mathrm{Chl} b$, respectively) were determined according to equations 1 and 2, and the results expressed in terms of fresh weight $\left(\mathrm{mg} \mathrm{g}^{-1}\right)$. Values for total chlorophyll $\left(\mathrm{Chl}_{\text {total }}\right.$ $=\mathrm{Chl} a+\mathrm{Chl} b)$ and the $\mathrm{Chl} a / \mathrm{Chl} b$ ratio were calculated, as follows:.

$\mathrm{Chl} a=\left\{\left[\left(12.7 \times \mathrm{A}_{663 \mathrm{~nm}}-(2.69 \times 645 \mathrm{~nm})\right] \mathrm{x} 7 \mathrm{~mL}\right\} /\right.$ [mass (mg)x 1000] Eq. 1

$\mathrm{Chl} b=\left\{\left[\left(22.9 \quad \mathrm{x} \quad \mathrm{A}_{645 \mathrm{~nm}}-(4.48 \times 663 \mathrm{~nm})\right] \mathrm{x}\right.\right.$ $7 \mathrm{~mL}\} /[\operatorname{mass}(\mathrm{mg}) \times 1000] \quad$ Eq. 2

Descriptive microscopic analyses of the median regions of the middle-third of " $D$ " leaves from 14 month-old plants $(n=3)$ were performed using an light microscope. Paradermal and cross sections of leaves were hand-cutusing sharp steel blades, stained with either Safranin-Astra blue (KRAUS; ARDUIN, 1997) or Sudan III (for histochemical detection of the epidermis), and mounted ontosemi-permanent slides using glycerinated gelatin. Images of the paradermal and cross sections were projected onto white paper with the aid of a Zeiss Opton camera attached to the microscope, and the thicknesses of the tissues and stomata, respectively, were estimated using a micrometer scale. The contours of the cells of the epidermis, hypodermis and chlorophyll parenchyma were copied and measured.

Temporary slides of the abaxial surfaces of leaves were prepared with colorless varnish to allow examination of frontal views of the epidermis and to determine stomatal densities and the dimensions of guard cells and stomatal pores (BARBOZA et al., 2006). Images of known areas $(200 \times 200 \mu \mathrm{m})$ were projected as described above and the numbers of stomata per $\mathrm{mm}^{2}$ contained therein were counted. The lengths (longitudinal axis between the poles) and widths (transversal axis at the mid portion of the cell) of the guard cells were measured, and the dimensions of the stomatal pores evaluated.

The mean masses of pineapple fruit $(\mathrm{kg}$ fruit $\left.^{-1}\right)$ and cassava roots $\left(\mathrm{kg}\right.$ plant $\left.^{-1}\right)$ were determined by weighing the organs produced by the individual plants grown in that plot and multiplied 
by the number of plants distributed in a hectare. The percentage of fruits damaged by solar radiation was established by counting those that presented a yellowish color on the surface that had been exposed to the sun.

Land-use efficiency was determined from the sum of the quotients of intercropping yield (B) and monoculture yield (M) calculated for each species according to equation 3 :

Land - use efficiency $=\frac{B_{\text {pineapple }}}{M_{\text {pineapple }}}+\frac{B_{\text {cassava }}}{M_{\text {cassava }}}$ Eq. 3

Analysis of variance (ANOVA) was performed on the original data since the assumptions of normality of residuals and homogeneity of variances were obeyed, with the exception of those relating to sunburned fruits. When an $F$ value indicated a difference between treatments, mean values were compared using the Scott-Knott test at the $5 \%$ probability level for qualitative factors (intercropping/monoculture systems) and regression analysis was carried for the quantitative factors (shading treatments). Data relating to the percentages of fruits exhibiting damage from sun light were heteroscedastic and were analyzed using the non-parametric Friedman test at the $5 \%$ probability level.

\section{RESULTS AND DISCUSSION}

The variations in the morphological and chemical characteristics of the "D" leaves of pineapple are presented in Table 2. The leaves of plants cultivated under higher levels of shading in spacings between the cassava plants: $0.50 \mathrm{~m} ; 0.75 \mathrm{~m}$ and $1.0 \mathrm{~m}$, were significantly $(P<0.05)$ longer than those grown under less shade (spacing $01.25 \mathrm{~m}$ ) or in sunlight (pineapple monoculture). Such increased length represents a phototropic response associated with the optimization of photosynthetic performance (TAKEMIYA et al., 2005). Interestingly, the areas of " $D$ " leaves were not influenced significantly by any of the treatments.

Table 2. Morphological and chemical characteristics of " $D$ " leaves from 14 month-old pineapple plants (Smooth Cayenne group, cultivar Rio Branco 1) cultivated under various degrees of shade provided by cassava plants

\begin{tabular}{ccccccc}
\hline \multirow{2}{*}{ Spacing $(\mathrm{m})$} & \multicolumn{7}{c}{ Variable $^{1}$} \\
\cline { 2 - 6 } & $\begin{array}{c}\text { Length } \\
(\mathrm{cm})\end{array}$ & $\begin{array}{c}\text { Area } \\
\left(\mathrm{cm}^{2}\right)\end{array}$ & $\begin{array}{c}\text { Chl } a \\
\left(\mathrm{mg} \mathrm{g}^{-1}\right)\end{array}$ & $\begin{array}{c}\mathrm{Chl} b \\
\left(\mathrm{mg} \mathrm{g}^{-1}\right)\end{array}$ & $\begin{array}{c}\text { Chl } a / \text { Chl } b \\
\text { ratio }\end{array}$ & $\begin{array}{c}\mathrm{Chl}_{\text {total }} \\
\left(\mathrm{mg} \mathrm{g}^{-1}\right)\end{array}$ \\
\hline 0.50 & $105.0^{\mathrm{a}}$ & $465.5^{\mathrm{a}}$ & $0.86^{\mathrm{a}}$ & $0.30^{\mathrm{a}}$ & $3.01^{\mathrm{a}}$ & $1.18^{\mathrm{a}}$ \\
0.75 & $105.0^{\mathrm{a}}$ & $448.0^{\mathrm{a}}$ & $0.85^{\mathrm{a}}$ & $0.31^{\mathrm{a}}$ & $2.80^{\mathrm{a}}$ & $1.19^{\mathrm{a}}$ \\
1.00 & $105.7^{\mathrm{a}}$ & $472.2^{\mathrm{a}}$ & $0.94^{\mathrm{a}}$ & $0.31^{\mathrm{a}}$ & $3.13^{\mathrm{a}}$ & $1.26^{\mathrm{a}}$ \\
1.25 & $98.7^{\mathrm{b}}$ & $431.3^{\mathrm{a}}$ & $0.70^{\mathrm{b}}$ & $0.26^{\mathrm{a}}$ & $2.82^{\mathrm{a}}$ & $0.98^{\mathrm{b}}$ \\
Monoculture $_{\text {CV }(\%)}^{97.0^{\mathrm{b}}}$ & $453.2^{\mathrm{a}}$ & $0.69^{\mathrm{b}}$ & $0.30^{\mathrm{a}}$ & $2.33^{\mathrm{a}}$ & $0.99^{\mathrm{b}}$ \\
\hline F value & 4.36 & 10.67 & 9.49 & 10.27 & 11.76 & 8.02 \\
\hline
\end{tabular}

${ }^{1}$ Within a column, mean values $(n=60)$ bearing similar superscript lowercase letters are not significantly different (Scott-Knott test; $P$ $<0.05) ;{ }^{2}$ Values classified as not significant (ns), significant at 5\% (*) or significant at $1 \%(* *)$; Abbreviations: Chl, chlorophyll; CV, coefficient of variation.

Concentrations of Chla and $\mathrm{Chl}_{\text {total }}$ were significantly $(P<0.05)$ lower in the leaves of pineapple plants that had received minimal shading $(1.25 \mathrm{~m})$ or had been exposed to direct sunlight (Monoculture). According to Almeida et al. (2005), the lower accumulation of chlorophyll in such leaves compensates for the higher levels of light intensity. Under conditions of appropriate radiation, chlorophyll molecules are synthesized and degraded at the same rate, but in the presence of excess sunlight, the rate of degradation is intensified (FERREIRA et al., 2012). No differences between treatments were observed with respect to the concentrations of $\mathrm{Chl} b$ or $\mathrm{Chl} a / \mathrm{Chl} b$ ratios (Table 2).

The "D" leaves of pineapple were hypostomatic (Figure 1A) with stomata distributed in parallel layers (Figures $1 \mathrm{~B}$ and 1C) as described by Barboza et al. (2006). The abaxial (Figure 1D) and adaxial (Figure 1E) epidermal surfaces were unistratified, un curled and consisted of cells with thick anticlinal cell walls but without chlorophyll (PROENÇA; SAJO, 2007). The mesophyll exhibited dorsiventral organization, with the aquiferous hypodermis immediately adjacent to the adaxial epidermis present in grounded, thin walled non-chlorophyllous cells, sub adjacent layers of 
elongated anticlinal cells (PROENÇA; SATO, 2007) and chlorophyll parenchyma distributed under the aquifer hypodermis in the form of rounded cells organized as a palisade.

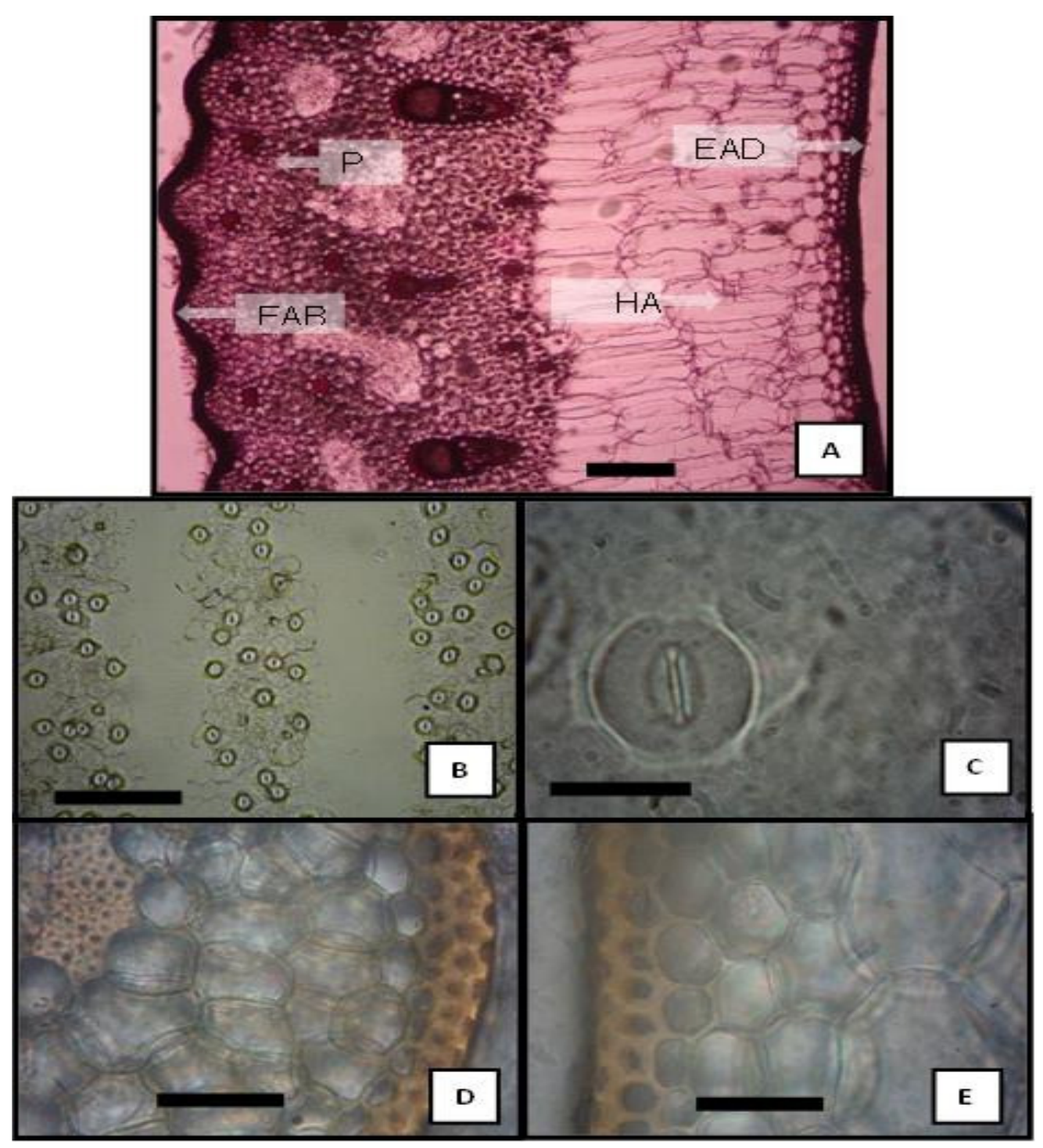

Figure 1. Microscopic analysis of a pineapple leaf blade: (A) Cross section showing the adaxial (ADE) and abaxial (ABE) epidermis, the aquiferous hypodermis $(\mathrm{AH})$ and the chlorophyll parenchyma $(\mathrm{CP})$; (B) Paradermal section showing the stomata arranged in longitudinal layers; (C) Paradermal section showing the frontal view of a stoma; (D) Cross section showing ABE; (E) Cross section showing ADE. $B a r=200 \mu \mathrm{m}(A$ and B $), 20 \mu \mathrm{m}(C), 50 \mu \mathrm{m}(\mathrm{D}$ and $\mathrm{E})$.

The variations in the histological characteristics of the " $\mathrm{D}$ " pineapple leaves are presented in Table 3. The thicknesses of the mesophyll and the leaf blade of pineapple were significantly greater $(P<0.05)$ in plants grown under shade $(0.50$ at $1.25 \mathrm{~m})$ in comparison with those grown in the sunlight (monoculture). Increases in the thicknesses of these tissues were associated with the significant expansion $(P<0.05)$ of the aquiferous hypodermis under conditions of reduced light intensity. According to Rozendaal et al (2006), plants developed in shaded environments invest more in light-capturing complexes, while expansion of the aquiferous hypodermis layer reportedly assists in the scattering of diffuse light under conditions of low radiance (MARKESTEIJN et al., 2007). No alterations in the chlorophyll parenchyma were observed in any of the treatments (Table 3).

The thicknesses of the abaxial and adaxial epidermal layers of leaves of pineapple plants cultivated under direct sunlight were significantly $(P$ $<0.05)$ greater in comparison with plants grown under shade conditions ( 0.50 at $1.00 \mathrm{~m}$ spacings) (Table 3$)$. Increased thickness of the epidermis represents a structural adaptation to minimize the effect of high solar radiation (MARKESTEIJN et al., 2007) and 
constitutes an important parameter in the adaptation of a plant to the variation in light intensity
(ROZENDAAL et al., 2006; SARIJEVA et al., 2007).

Table 3. Histological characteristics of " $D$ " leaves from 14 month-old pineapple plants (Smooth Cayenne group, cultivar Rio Branco 1) cultivated under various degrees of shade provided by cassava plants

\begin{tabular}{|c|c|c|c|c|c|c|c|}
\hline \multirow{2}{*}{ Variable $^{1}$} & \multicolumn{5}{|c|}{ Cassava spacings $^{2}$} & \multirow{2}{*}{$\begin{array}{l}\mathrm{CV} \\
(\%)\end{array}$} & \multirow{2}{*}{$F$ value $^{2}$} \\
\hline & 0.50 & 0.75 & 1.00 & 1.25 & $\begin{array}{c}\text { pineapple } \\
\text { monoculture }\end{array}$ & & \\
\hline Thickness of mesophyll $(\mu \mathrm{m})$ & $1.944^{\mathrm{a}}$ & $1.999^{\mathrm{a}}$ & $2.033^{\mathrm{a}}$ & $2.042^{\mathrm{a}}$ & $1.748^{\mathrm{b}}$ & 5.36 & $5.365^{*}$ \\
\hline Total thickness of leaf blade $(\mu \mathrm{m})$ & $1.966^{\mathrm{a}}$ & $2.020^{\mathrm{a}}$ & $2.054^{\mathrm{a}}$ & $2.066^{\mathrm{a}}$ & $1.776^{\mathrm{b}}$ & 5.29 & $5.145^{*}$ \\
\hline Thickness of aquiferous hypodermis $(\mu \mathrm{m})$ & $803^{\mathrm{a}}$ & $848^{\mathrm{a}}$ & $866^{\mathrm{a}}$ & $867^{\mathrm{a}}$ & $570^{\mathrm{b}}$ & 6.80 & $24.580 * *$ \\
\hline Thickness of chlorophyll parenchyma $(\mu \mathrm{m})$ & $1.206^{\mathrm{a}}$ & $1.172^{\mathrm{a}}$ & $1.187^{\mathrm{a}}$ & $1.199^{\mathrm{a}}$ & $1.206^{\mathrm{a}}$ & 5,12 & $0.208^{\mathrm{ns}}$ \\
\hline Thickness of abaxial epidermis $(\mathrm{m} \mu)$ & $10.5^{\mathrm{b}}$ & $10.5^{\mathrm{b}}$ & $9.9^{\mathrm{b}}$ & $11.2^{\mathrm{b}}$ & $13.3^{\mathrm{a}}$ & 8.16 & $8.114^{* *}$ \\
\hline Thickness of adaxial epidermis $(\mathrm{m} \mu)$ & $11.1^{\mathrm{b}}$ & $10.9^{\mathrm{b}}$ & $10.7^{\mathrm{b}}$ & $12.6^{\mathrm{a}}$ & $14.8^{\mathrm{a}}$ & 10.33 & $7.849 * *$ \\
\hline Stomatal density $\left(\right.$ stoma $\mathrm{mm}^{-2}$ ) & $92.7^{\mathrm{b}}$ & $81.5^{\mathrm{c}}$ & $93.1^{\mathrm{b}}$ & $108.9^{\mathrm{a}}$ & $116.2^{\mathrm{a}}$ & 6.57 & $18.581^{* *}$ \\
\hline Length of stomatal pore $(\mathrm{m} \mu)$ & $15.78^{\mathrm{b}}$ & $15.61^{\mathrm{b}}$ & $15.26^{\mathrm{b}}$ & $15.62^{\mathrm{b}}$ & $16.67^{\mathrm{a}}$ & 2.29 & $4.235^{*}$ \\
\hline Width of stomatal pore $(\mathrm{m} \mu)$ & $1.49^{\mathrm{b}}$ & $1.38^{\mathrm{b}}$ & $1.54^{\mathrm{b}}$ & $1.48^{\mathrm{b}}$ & $1.83^{\mathrm{a}}$ & 2.90 & $11.591^{* *}$ \\
\hline Length of guard cells $(\mathrm{m} \mu)$ & $33.54^{\mathrm{a}}$ & $32.54^{\mathrm{a}}$ & $32.97^{\mathrm{a}}$ & $32.57^{\mathrm{a}}$ & $34.29^{\mathrm{a}}$ & 2.26 & $3.093^{\mathrm{ns}}$ \\
\hline Width of guard cells $(\mathrm{m} \mu)$ & $13.36^{\mathrm{b}}$ & $13.05^{\mathrm{b}}$ & $13.13^{\mathrm{b}}$ & $13.33^{\mathrm{b}}$ & $14.29^{\mathrm{a}}$ & 2.26 & $10.333^{* *}$ \\
\hline
\end{tabular}

${ }^{1}$ Within a row, mean values $(n=120)$ bearing similar superscript lowercase letters are not significantly different (Scott-Knott test; $P$ $<0.05) ;{ }^{2}$ Values classified as not significant (ns), significant at 5\% (*) or significant at $1 \%(* *)$; Abbreviation: CV, coefficient of variation.

Stomatal density in pineapple leaves tended to increase in plants grown under conditions of greater luminosity $(1.00 \mathrm{~m}$ of spacing and pineapple monoculture), with values ranging from 81.5 stoma $\mathrm{mm}^{2}$ in shaded areas to 116.2 stoma $\mathrm{mm}^{2}$ in direct sunlight. Increased stomatal density in plants cultivated under high light intensity is a mechanism of adaptation to optimize long-term gas exchange and photosynthetic activity under such conditions (SCHLUETER et al., 2003).

The lengths and widths of the stomatal pores were significantly $(P>0.05)$ greater in the leaves of pineapple plants grown in sunlight compared with those of shaded plants. While, the lengths of guard cells were similar for all leaves analyzed, irrespective of shade treatment, the widths of these cells were significantly $(P>0.05)$ greater in leaves from plants grown in sunlight, and this may reflect the increased dimensions of the stomatal pores (Table 3). According to Hetherington and Woodward (2003), morphological alterations in the stomatal pores and guard cells may be associated with the increased stomatal conductance in leaves exposed to high solar radiation, constituting a strategy to increase transpiration efficiency and reduce leaf temperature.
As expected, the percentage of sunburned pineapple fruits was significantly $(P<0.05)$ greater in plants cultivated in direct sunlight (pineapple monoculture) compared with shade-grown plants (Table 4). The spacing of $0.75 \mathrm{~m}$ between cassava shade plants, provided not only the best protection against solar radiation but also generated fruits with the highest mean mass and with the highest yield per hectare.

In the intercropping system, the yield of cassava roots per plant exhibited a direct linear correlation with the distance apart of the plants, while the yield of roots per ha showed an inverse linear correlation with plant spacing (Figure 2). Although the yield per plant increased by $2.2 \mathrm{~kg}$ for each additional $\mathrm{m}$ of plant spacing, the corresponding yield per ha was reduced by $10,068.99 \mathrm{~kg}$. Thus, decreasing the density of plants from 14.280 plants $\mathrm{ha}^{-1}(0.5 \mathrm{~m}$ spacing $)$ to 5.712 plants $\mathrm{ha}^{-1}(1.25 \mathrm{~m}$ spacing) resulted in a reduction in total yield even though the yield per plant was higher in the latter situation. In high-density crops, the self-shaded plants have to compete for the limited light that filters through the canopy, and this reduces the photosynthetic activity and consequently the yield (AGUIAR et al., 2011). 
Table 4. Yields of pineapple fruits from 14 month-old pineapple plants (Smooth Cayenne group, cultivar Rio Branco 1) cultivated under various degrees of shade provided by cassava plants

\begin{tabular}{ccccc}
\hline $\begin{array}{c}\text { Cassava } \\
\text { spacings }\end{array}$ & $\begin{array}{c}\text { Sunburned fruit } \\
(\%)\end{array}$ & $\begin{array}{c}\text { Mean mass of fruit }{ }^{2}(\mathrm{~kg} \\
\left.\text { fruit }^{-1}\right)\end{array}$ & $\begin{array}{c}\text { Yield of fruit }^{2} \\
\left(\mathrm{~kg} \mathrm{ha}^{-1}\right)\end{array}$ & $\begin{array}{c}\text { Land-use } \\
\text { efficiency }^{1}\end{array}$ \\
\hline 0.50 & $2.5^{\mathrm{b}}$ & $1.368^{\mathrm{b}}$ & $18,606.25^{\mathrm{b}}$ & $2.04^{\mathrm{a}}$ \\
0.75 & $0.0^{\mathrm{b}}$ & $1.635^{\mathrm{a}}$ & $24,501.53^{\mathrm{a}}$ & $2.12^{\mathrm{a}}$ \\
1.00 & $10.6^{\mathrm{b}}$ & $1.233^{\mathrm{b}}$ & $18,462.10^{\mathrm{b}}$ & $1.71^{\mathrm{b}}$ \\
1.25 & $0.0^{\mathrm{b}}$ & $1.315^{\mathrm{b}}$ & $19,702.08^{\mathrm{b}}$ & $1.75^{\mathrm{b}}$ \\
Pineapple & $45.0^{\mathrm{a}}$ & $1.240^{\mathrm{b}}$ & $18,606.25^{\mathrm{b}}$ & - \\
monoculture & & & & - \\
\hline CV $(\%)$ & - & 10.05 & $4.105^{*}$ & -6.67 \\
$F$ value & - & $4.098^{*}$ & 4.107 \\
\hline
\end{tabular}

Within a column, mean values bearing similar superscript lowercase letters are not significantly different (non-parametric Friedman test; $P<0.05){ }^{2} \quad$ Within a column, mean values bearing similar superscript lowercase letters are not significantly different (ScottKnott test; $P<0.05){ }^{3} \quad$ Values classified as significant at $5 \%(*)$.

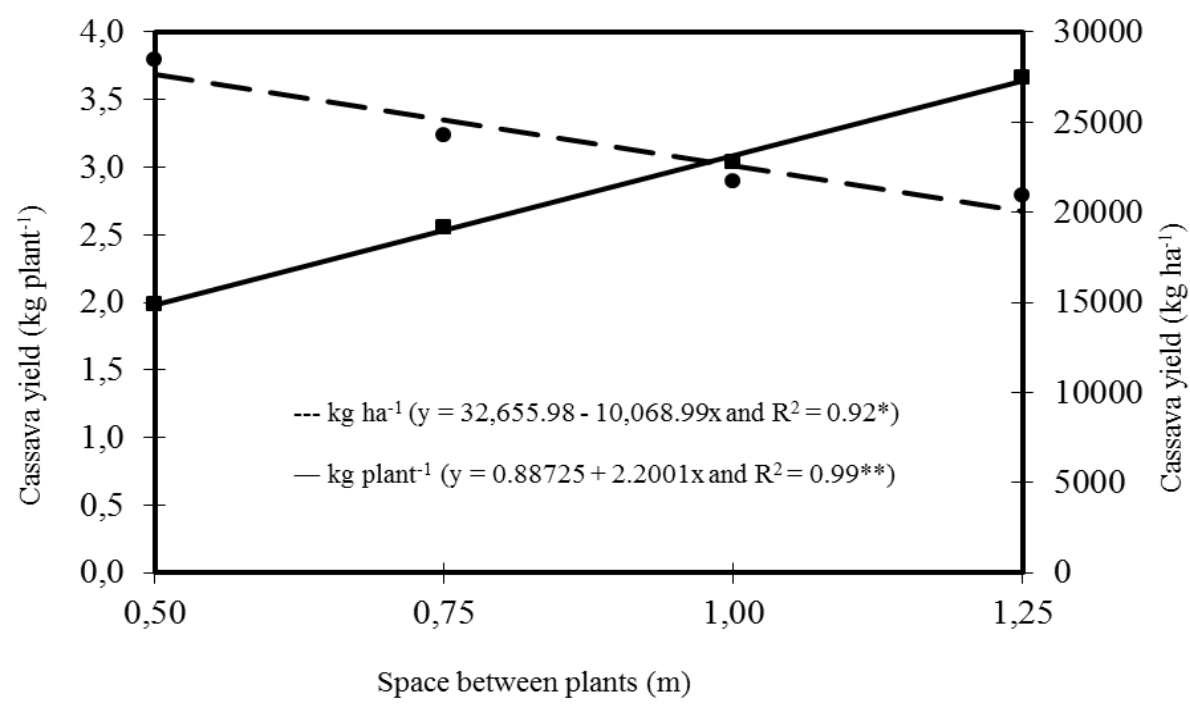

Figure 2. Yield of cassava in intercropping with pineapple plant. The differences between treatments were significant in terms of yield per plant $(* * F$ at $1 \%$ probability $=25.284)$ and yield per unit area $(* F$ at $5 \%$ probability $=3.976)$.

Land-use efficiency values were $>1$ for all intercropping systems (Table 4), indicating that between 1.71 to 2.12 ha of the monocultures would be required to produce the same amount as 1 ha of the intercropping. The highest land-use-efficiency was obtained with shade in $0.75 \mathrm{~m}$ spacing followed closely by $0.50 \mathrm{~m}$ spacing.

Along with increased yield, the intercropping system offers the additional advantage of diversity of products with dual purpose. According to Grisa (2007), agricultural systems of this type allow for greater food and economic security in family farming since products such as cassava have exchange value, if market prices are favorable, or may be consumed by the family in order to minimize expenditure on food at the market.
Additionally, the sale of highly marketable products such as pineapple guarantees reimbursement of expenses for services and external inputs, and produces investment in property.

\section{CONCLUSIONS}

Pineapple plants grown under conditions of shade created by adjacent cassava plants presented phenotypic plasticity and exhibited longer and thicker " $D$ " leaves with higher chlorophyll content, reduced stomatal density and dimensions of stomatal pores, narrower guard cells, thinner aquiferous hypodermis, and reduced abaxial and adaxial epidermis. 
The maximum yield of pineapple fruit, was achieved using an intercropping system in which shade was provided by cassava plants spaced $0.75 \mathrm{~m}$ apart. Under these conditions, fruits were fully protected against damage by solar radiation.

The yield of cassava roots per plant increased linearly with increasing distance between the plants, but the yield per ha decreased with decreasing plant density.

\section{ACKNOWLEDGMENTS}

The authors are grateful to the Coordenação de Aperfeiçoamento de Pessoal de Nível Superior (CAPES) and the Conselho Nacional de Desenvolvimento Científico e Tecnológico (CNPq) for grants awarded to the authors.

RESUMO: Os objetivos desse trabalho foram avaliar o efeito do sombreamento no abacaxizeiro com mandioca, sobre a produtividade de abacaxi e raízes de mandioca, sobre a variação morfoanatômica, queimadura do abacaxi pela radiação e os teores de clorofilas nas folhas do abacaxizeiro. As plantas de abacaxizeiro foram cultivadas em parcelas compreendendo linhas triplas paralelas (segundo um arranjo triangular) sob diferentes condições de sombreamentos proporcionadas por plantas de mandioca cultivadas em linhas simples em cada lado das parcelas. O delineamento utilizado foi de blocos casualizados com cinco tratamentos (sombreamento com mandioca em espaçamentos de 0,50, 0,75, 1,00 e $1,25 \mathrm{~m}$ e monocultivo de abacaxi) e quatro repetições. As produtividades de abacaxi e mandioca, juntamente com as características morfológicas, químicas e histológicas da folhas "D" dos abacaxizeiros, foram determinadas 14 meses após o plantio. Os dados foram submetidos à análise de variância com teste de Scott-Knott ou teste de Friedman $(P<0,05)$ bem como análise de regressão. Abacaxizeiros cultivados sob sombreamento produziram frutos com maior peso médio e maior produtividade por hectare em comparação com plantas cultivadas sob luz solar direta. A máxima produtividade de abacaxi foi alcançada quando o espaçamento entre as plantas de mandioca foi de $0,75 \mathrm{~m} \mathrm{e}$, sob essas condições, os frutos ficaram completamente protegidos da radiação solar. As folhas "D" dos abacaxizeiros sombreados foram mais longas e espessas, apresentaram maior concentração de clorofila $a$ e total, densidade estomática reduzida, poros estomáticos menores, células guarda mais estreitas, hipoderme aquífera mais fina e epidermes abaxial e adaxial reduzidas. A produtividade de mandioca por planta aumentou linearmente com o espaçamento crescente, porém a produtividade por hectare diminuiu com o decréscimo da densidade das plantas.

PALAVRAS CHAVE: Anana comosus. Manihot esculenta. Plasticidade fenotípica. Cultivo consorciado.

\section{REFERENCES}

AGUIAR, E. B.; VALLE, T. L.; LORENZI, J. O.; KANTHACK, R. A. D.; MIRANDA FILHO, H.; GRANJA, N. do P. Efeito da densidade populacional e época de colheita na produção de raízes de mandioca de mesa. Bragantia, Campinas, v. 70, n. 3, p. 561-569, 2011. http://dx.doi.org/10.1590/S0006-87052011000300011 http://dx.doi.org/10.1590/S0006-87052011005000010

AL AFAS, N.; MARRON, N.; CEULEMANS, R. Clonal variation in stomatal characteristics related to biomass production of 12 poplar (Populus) clones in a short rotation coppice culture. Environmental and Experimental Botany, Amsterdã, n. 58, p. 279-286, 2006.

ALMEIDA, S. M. Z.; SOARES, A. M.; CASTRO, E. M. de; VIEIRA, C. V.; GAJEGO, E.B. Alterações morfológicas e alocação de biomassa em plantas jovens de espécies florestais sob diferentes condições de sombreamento. Ciência Rural, Santa Maria, v. 35, n. 1, p. 62-68, 2005. http://dx.doi.org/10.1590/S010384782005000100010

ANDRADE NETO, R. C.; NEGREIROS, J. R. S.; ARAÚJO NETO, S. E. de; CAVALCANTE, M. J. B.; ALECIO, M. R.; SANTOS, R. S. Diagnóstico da potencialidade da fruticultura no Acre. Rio Branco, AC: Embrapa Acre (Série Documentos - EMBRAPA), 2011.

ARAÚJO NETO, S. E. de; CAMPOS, P. A.; TAVELlA, L. B.; SOLINO, A. J. da S.; SILVA, I. F. Organic polyculture of passion fruit, pineapple, corn and cassava: the influence of green manure and distance between espaliers. Ciência \& Agrotecnologia, Lavras, v. 38, n. 3, p. 247-255, maio./jun., 2014.

http://dx.doi.org/10.1590/s1413-70542014000300004 
ARNON, D. I. Copper enzymes in isolated chloroplasts: polyphenoloxydase in Beta vulgaris. Plant Physiology, Maryland, v. 24, n. 1, p. 1-15, 1949. http://dx.doi.org/10.1104/pp.24.1.1

BARBOZA, S. B. S. C.; GRACIANO-RIBEIRO, D.; TEIXEIRA, J. B. PORTES, T.A.; SOUZA, L. A. C. Anatomia foliar de plantas micropropagadas de abacaxi. Pesquisa Agropecuária Brasileira, Brasília, DF, v. 41, n. 2, p. 185-194,2006. http://dx.doi.org/10.1590/S0100-204X2006000200002

BEZERRA NETO, F.; PORTO, V. C. N.; GOMES, E. G.; CECÍLIO FILHO, A. B.; MOREIRA, J. N. Assessment of agroeconomic indices in polycultures of lettuce, rocket and carrot through uni and multivariate approaches in semi-arid Brazil. Ecological Indicators, v. 14, n. 1, p. 11-17, 2012.

http://dx.doi.org/10.1016/j.ecolind.2011.07.006

CARVALHO, R. F.; TAKAKI, M.; AZEVEDO, R. A. Plant pigments: the many faces of light perception. Acta Physiologiae Plantarum, Kraków, v. 33, n. 2, p. 241-248, 2010. http://dx.doi.org/10.1007/s11738-010-0533-7

CECÍLIO FILHO, A. B.; REZENDE, B. L. A.; BARBOSA, J. C.; GRANGEIRO, L. C. Agronomic efficiency of intercropping tomato and lettuce. Anais da Academia Brasileira de Ciências, v. 83, n. 3, p. 1109-1119, 2011. http://dx.doi.org/10.1590/S0001-37652011000300029

CUNHA, G. A. P. DA; HAROLDO, D. Cuidados para evitar queima solar no abacaxi. Revista Frutas e derivados, Ano 3, Edição 9, p. 17, 2008.

DUZ, S. R.; SIMINSKI, A.; SANTOS, M.; PAULILO, M. T. Crescimento inicial de três espécies arbóreas da Floresta Atlântica em resposta à variação na quantidade de luz. Revista Brasileira de Botânica, São Paulo, v. 27, n. 3, p. 587-596, 2004. http://dx.doi.org/10.1590/s0100-84042004000300018

FERREIRA, W. N.; ZANDAVALLI, R. B.; BEZERRA, A. M. E.; MEDEIROS FILHO, S. Crescimento inicial de Piptadenia stipulacea (Benth.) Ducke (Mimosaceae) e Anadenanthera colubrina (Vell.) Brenan var. cebil (Griseb.) Altshul (Mimosaceae) sob diferentes níveis de sombreamento. Acta Botanica Brasilica, Feira de Santana, v. 26, n. 2, p. 408-414, 2012.

GRISA, C. Para além da alimentação: papeis e significado da produção para autoconsumo na agricultura familiar. Revista Extensão Rural, Porto Alegre, v. 14, p. 13-54, 2007.

HETHERINGTON, A. M.; WOODWARD, F. I. The role of stomata in sensing and driving environmental change. Nature, Lancaster, v. 424, p. 901-908, 2003. http://dx.doi.org/10.1038/nature01843

KIM, G.; YANO, S.; KOZUKA, T.; TSUKAYA, H. Photomorphogenesis of leaves: shade-avoidance and differenciation of sun and shade leaves. Photochemetry, Photobiology and Science, Cambridge, v. 4, n. 5, p. 770-774, 2005. http://dx.doi.org/10.1039/b418440h

KRAUS, J. E.; ARDUIN, M. Manual básico de métodos em morfologia vegetal. Seropédica: Editora Universidade Rural, 1997.

MARKESTEIJN, L.; POORTER, L.; BONGERS, F. Light-dependent leaf trait variation in 43 tropical dry forest tree species. American Journal of Botany. St. Louis v. 94, n. 4, p. 515-525, 2007. http://dx.doi.org/10.3732/ajb.94.4.515

PROENÇA, S. L.; SAJO, M das G. Anatomia foliar de bromélias ocorrentes em áreas de cerrado do Estado de São Paulo, Brasil. Acta Botanica Brasílica, Feira de Santana, v. 21, n. 3, p. 657-673, 2007.

PYPERS, P.; SANGINGAB, J. M.; KASEREKAB, B.; WALANGULULUC, M.; VANLAUWEA, B. Increased productivity through integrated soil fertility management in cassava-legume intercropping systems in 
the highlands of Sud-Kivu, DR Congo. Field Crops Research, v. 120, p. 76-85, 2011.

http://dx.doi.org/10.1016/j.fcr.2010.09.004

ROZENDAAL, D. M. A.; HURTADO, V. H.; POORTER, L. Plasticity in leaf traits of 38 tropical tree species in response to light; relationships with light demand and adult stature. Functional Ecology, London, v. 20, n. 2, p. 207-216, 2006. http://dx.doi.org/10.1111/j.1365-2435.2006.01105.x

SARIJEVA, G.; KNAPP, M.; LICHTENTHALER, H. K. Differences in photosynthetic activity, chlorophyll and carotenoid levels, and in chlorophyll fluorescence parameters in green sun and shade leaves of Ginkgo and Fagus. Journal of Plant Physiology, Ohio, v. 164, n. 7, p. 950 - 955, 2007.

http://dx.doi.org/10.1016/j.jplph.2006.09.002

SCHLUETER, U.; MUSCHAK, M.; BERGER, D.; ALTMANN, T. Photosynthetic performance of an Arabidopsis mutant with elevated stomatal density (sdd1-1) under different light regimes. Journal of Experimental Botany, Oxford, v. 54, n. 383, p. 867-874, 2003. http://dx.doi.org/10.1093/jxb/erg087

TAKEMIYA, A., INOUEA, S., DOIB, M., KINOSHITAA, T., SHIMAZAKIA, K. Phototropins promote plant growth in response to blue light in low light environments. The Plant Cell, Waterbury, v. 17, p. 1120-1127, 2005. http://dx.doi.org/10.1105/tpc.104.030049

VOLTOLINI, C. H.; SANTOS, M. Variações na morfoanatomia foliar de Aechmea lindenii (E. Morren) Baker var. lindenii (Bromeliaceae) sob distintas condições ambientais. Acta Botanica Brasilica, Feira de Santana, v. 25, n. 1, p. 2-10, 2011. http://dx.doi.org/10.1590/S0102-33062011000100002 